\title{
EDUBLOGS: A MEDIA TO IMPROVE STUDENTS' WRITING SKILL IN RECOUNT TEXT
}

\author{
Diki Riswandi, Ngadiso, Abdul Asib \\ Universitas Sebelas Maret \\ dikiriswandi@gmail.com
}

\begin{abstract}
This study designed to improve students' writing skills through Edublogs of one Senior High Schools in Indonesia. Based on the preliminary observation, several problems were found in the field such as students' poor writing skills and low interest toward writing, inappropriate teacher's style in teaching, the role of media and the unsuitable utilization of internet facility. The students had some problems in recount text writing, i.e. the generic structure, the purpose and the language features. In addition, they had no capability to make a self-reflection on their own mistakes. It happens since their teacher has a tendency to directly correct the mistakes. This current research was an action research study consisting of two cycles. There are 23 students involved in this study. The data of this study were qualitative and quantitative. The qualitative data were obtained, the first, by observing the teaching and learning process during the implementation of the actions and the second, by interviewing the students and the collaborator about the actions implemented. Furthermore, the qualitative data were in the form of field notes and interview transcripts. Meanwhile, the quantitative data were gained by assessing the students' writing skills through the pretest and posttest. The qualitative data were analyzed using the qualitative data analysis those are data collection, data reduction, data display, and conclusion drawing and verification. The results of this study show that Edublogs is an effective media that can be used to improve students' writing skills qualitatively and quantitatively. Qualitatively, using Edublogs, teaching and learning process became more interesting. The students enjoyed the writing process. The students' problems in writing can be reduced by using Edublogs in teaching-learning process by applying writing stages through Edublogs. Quantitatively, the average score gained by the students in cycle one was 67.37 while in cycle two is 72.58 . The results show that students' writing skill improves significantly through blogging activity. Thus, it can be concluded that the students are more enthusiastic and more interested in writing English.
\end{abstract}

Keywords: Edublogs, Blog, Writing, Recount, High School Students

\section{Introduction}

Teaching English as a foreign language has become one of the crucial issues to discuss. Many researchers and experts have done researches on this field. The complexity of this issue has brought the topic to be wider and complex. There are four skills mostly which become the expert focus to conduct the research on this field. Writing is one of the most crucial skills. Richards and Renandya (2002) state that there is no doubt that writing is the most difficult skill for the second language learners to master. Learners need to combine a lot of components to compose a good writing, starting from grammar to cohesion and coherence in writing. These will be difficult points for many students to write. The difficulty lies not only in generating and organizing ideas, but also in translating these ideas into reada- ble text. This statement implies that as the productive skill, writing is really difficult to produce especially by the foreign learners or L2 learners.

Several schools in Indonesia mostly have the same problems with the students facing this lesson of English. To be more specific, the problems happen in the learning process of the first grade of one of senior high schools observed in Surakarta. In this class, there are some difficulties that relate to the English writing process faced by students. The students have low competency in writing; their understanding about skills of writing is poor. They have difficulties in taking words to the context when developing sentences, so they cannot compose a good paragraph. Their knowledge of grammar, diction, and cohesion and coherence are not promoted appropriately. Their sentences often contain a lot of gram- 
matical errors specially in using tenses. Learners need to improve their notion in term of vocabulary and diction.

However, to figure out the solution for these problems, it is undeniable that the existence of technology should be taken into account. The teacher should start to encompass the use technology into classroom. One of technology that is highly possible to help students improve their writing is using Web blog. Weblogs are one of popular examples of Web 2.0 applications - a web application that displays serial entries, asynchronously developed, by employing simple user interfaces and allowing users to easily preserve content or add new dated entries, with the benefits of inserting graphics, multimedia, video and audio, not to mention the text, which is an important aspect of blogging (Fageeh, 2011). There are lots of web blog flat forms offers the user to use blog. One of the best blog to use for the shake of education is Edublogs.

From the interviews and observation conducted prior to the research activity, the researcher found some information and data about the problems in the field. The problems are varied such as it is relating to the students' writing skills, students' interest toward writing, teachers' style in teaching, the role of media and the utilization of internet. Students still have no idea with the components of writing. The content, organization, cohesion, register, vocabulary and grammar of their writing are poor. In addition, students' condition and mode are important to keep in writing class. Writing is a product of students' ideas which is transferred into the products. However, the currents condition shows that during the learning process, students are not interested in writing. They feel bored and do not follow the lesson well. Innovative way of teaching in learning process is highly needed to trigger students' interest and engage them into writing class. Stimulating their interest is a crucial thing to do in teaching writing.

Furthermore, teaching the skills of writing to the learners is exceedingly needed. The way how the teacher delivers the materials in teaching gives consequence to the students' understanding about materials delivered. However, in the field researcher found that the teacher does not have innovative strategy in teaching. The style mostly used by the teacher was lecturing. The teacher talks frequently in front of the class. It makes the stu- dents bored and tired during the class. As the result, students do not pay attention to the teacher and prefer to talk with their friends.

The next problem found in the field relates to the media used by the teacher. As we can see that the function of media in teaching process is very vital. The media can help the students comprehend the materials well or likely better. Unfortunately, in this case the teacher is infrequently to use media as the tool of teaching and learning because the teacher does not have sufficient knowledge about media. The teacher is not quite accustomed to using the media such as laptop, computer, etc. The teacher prefers using old style teaching to the new one. Thus, that factor causes the learning process of the writing activity become uninterested.

Based on the problems mentioned above, the researcher emphasis on improving students' writing skill by using media for this problem is practicable for the researcher. This media is expected to be very helpful for the teacher and students to carry out the teaching and learning process. The researcher uses the Edublogs in the writing process. The researcher has two reasons for the use of Edublogs. The first, web blog is a communicative media for writing process. By giving blogging activities, the students can be more enthusiastic in the writing class. The second, the efforts that are done in this research are limited by physical factors such as the time. The objectives of the research are to identify the use of Edublogs as media to figure out whether the students' writing skill improves significantly through blogging activity.

\section{Literature Review}

Within education and academia, web logs are being comprised by both teachers and students. The web is an important and everevolving resource for teaching and learning. Martindale and Wiley (2005) argue that tools like HTML editors and FTP clients have made web publishing available to many teachers and students. However, the challenge of learning to use these tools has been a barrier to web publishing for many. They further suggest web logs reduce the technical barriers to effective web publishing significantly. "Blogs used for education, dubbed edublogs, are rapidly emerging as techno-savvy teachers embrace the instructional potential of this online 
tool" (Ray, 2006).

Edublogs is one of the internet-based free platform that provides the user to post their idea and thought in the form of blogs. Anderson in Raman et al. (2015, p. 500) mentions that Edublogs is an interactive web-based software that permits students to actualize themselves in a social environment. Edublogs is powered by wordpres.com, one of the biggest blog platforms, which focuses on the academic purposes. In short, it can be said that Edublogs is one of Blog platforms that allow users (students or teacher) to post their thought and idea.

Boas (2011, p. 28) says that a blog, which is derived from words of web and log, is a personal journal or diary using web-based page allowing the author to post varied articles that can be viewed and responded by world-wide audiences. Asoodar, Atai, \& Vaezi (2016, p. 226) say that blogs or also called weblogs are internet-based media that have replaced conventional learning logs in language instruction. Foster $(2015$, p. 105) takes the view that blogs are online repositories of individual entries or "posts" that are ordinarily displayed in reverse chronological order. They have facilitated the instantaneous act of micropublishing for hundreds of millions of people.

Eastman (2005, p. 358) states Blogs are online journals or diaries which consist of logs (weblogs) of thoughts, reflections and events in the writer's life with an option for readers to comment on what they have read and hence promoting the exchange of ideas between users. Mynard (2007, p. 1) mentions that A blog (or web log) is a kind of online diary that provides an authentic writing practice, opportunity to recycle language learned in class, and an alternative way of communicating with teachers and peers.

Churchill (2009, p. 179) mention that blogs nowadays started to emerge as a useful type of educational technology. Several literatures discuss a number of interesting possibilities for the use of blogs. Plenty of websites or platforms offer the free web-based blog in the internet which can be accessed by everyone such as Wordpress, Blogspot, Google Site, and Edublogs. With this in mind, the writer takes Edublogs as the media. Edublogs (2017) and Urbano \& Villanueva (2012, p. 2) mention several features provided in Edublogs as follows:

(1) Sharing materials, news, downloads, links and more. Teacher can share anything with their post to the blog then it will instantly be accessible by students from everywhere. (2) Facilitating online discussions and collaboration. Students can easily respond to teachers or their friends' blog posts and discuss topics through comments. (3) Creating a class publication that students can easily publish. (4) Getting students blogging so that they can share their work and thoughts. (5) Getting feedback or gather information.

\section{Method}

This study is classified into action research. According to Kemmis and McTaggart (1988) in Burns (2010: 7), "action research has four major steps. There are planning, action, observation and reflection". To conduct the research, the researcher made collaboration with the teacher of the English Class. The collaborative work included was to find a problem, formulated a possible solution, implemented the action, and reflected on the outcome of the action.

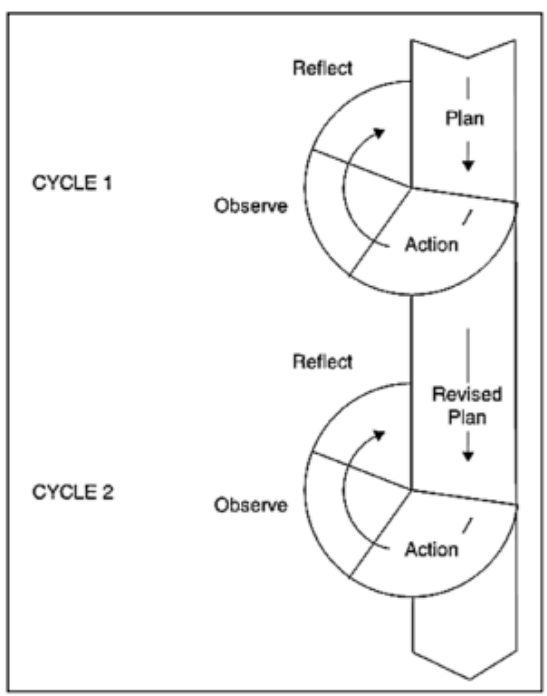

Figure 1 Cyclical Action Research Model Based on Kemmis and McTaggart

According to Kemmis and McTaggart (1988) in Burns (2010), planning is the identification process of problems or issues in order to compose a plan of action to bring improvements in a certain area of the research context. Action is the plan that is carefully considered one which includes some deliberate interventions into teaching process. The next is observation in which involves the researcher in observing the effect of the action and document 
ing all the process methodically. The last stage is reflection. At this stage, the researcher reflects on, evaluate and explain the effect of the action in order to make sense of what has happened and to understand the issue clearly.

Conducting the research, the researcher collaborates with the teacher of the class to have an observation and interview. There are several instruments used in this action research such as fieldnote, observation, interview guidance, questionnaire, and writing test. Fieldnote is the form of report of the result of observation during teaching and learning process. It depicts a clear description about the actions conducted by the teacher. The description includes the teaching learning process and the problems when the action is implemented.

To support the information described in the fieldnote, the researcher then uses the observation form. In this way the researcher observed what had happened in the classroom when the action plans were conducted. The observation included the students' attention, focus and interest and the problems when the action was implemented. In addition, instead of fieldnote and observation, the researcher also makes an interview with the teacher and students. The interview was conducted to get some data about the school, the teacher, the students, and the English teaching-learning process in that school. It was done before, while and after teaching-learning process. The interview involved the students the English teacher. To record the interview, the researcher used mobile phone to record the result of interview. The data were saved in audio records and interview transcripts.

Eventually, prior to writing test, the researcher takes the other data from the students by using questionnaire. The questionnaire was given to the participants to find out the level of students' motivation. It was a closed questionnaire. The questionnaire consisted of 20 items. The items were related to the students' perception of in writing after the learning process through Edublogs. The questionnaire was given on each cycle.

The last and important instrument of this research is writing test. The test was done to get students' writing score. The score was analyzed to find out whether the students have a significant progress in writing through Edublogs. The students were asked to make recount text as what it was stated on the sylla- bus. The students' writing contained the materials from basic competence at first grade of senior high school. The students directly wrote their work on Edublogs. The results of students' writing are publicly published. The form of the test was essay. The test was analyzed by Jacobs et al's scoring profile. The minimum score for passing grade was taken from the minimum passing criteria (KKM/ Kriteria Ketuntasan Minimum) of the school. It is 75 for passing the subject. The researcher and the teacher analyzed the writing test.

\section{Result and Discussion}

After the implementing a four-phase technique to improve students' writing skill, the researcher got some results dealing with both writing skill and class situation. The result is presented on Table 1.

In accordance with the table above, it reports that the students' improvement in writing skill is improved from before the action stage to the cycle two. Before conducting the action, it was reported that students had low scores in writing. It can be seen that the mean score was 58.11. Furthermore, after the implementation of Edublogs in cycle 1, it was found that there were some improvements in students writing skill. It is shown by the mean score of students' writing was 67.37. In this stage, however, some students still have errors in their writing such as being unable to use capitals for names and sentence in the beginning. In short, at the end of the cycle 1 after having feedback and revision, the score is better than pre-test. In cycle 2 , the findings showed that the students' skill of writing had improved affectedly in writing score. The average score of students' writing in this stage is 72.58 .

From the improvement achieved by the students, it is clearly seen that Edublogs used in the action can improve the students' writing skill through the activities in each phase. This idea is supported by several experts proposing Blog as media to teach writing. Noytim (2010) states that when the potential use and value of blogs in language learning was examined in Taiwan, the results revealed that there was a general acceptance of blogs by students as a productive tool to improve their language skills, such as writing, vocabulary, 
self-expression, socializing and thinking skills. In the same vein, Hashemi and Najafi (2011) mentions that the use of blogs has a positive impact on teaching writing skills to EFL learners. Arslan and Șahin-Kızıl (2010) observes that blog-based writing can play an important role in improving students' writing performance. Similarly, a study conducted by Koçoğlu (2009) reveals that the use of blogs was significant in terms of learners' writing and speaking skills.

Table 1 Table of the Improvement of Students'

\begin{tabular}{|l|c|c|c|c|c|c|}
\hline Aspect & $\mathbf{C}$ & $\mathbf{O}$ & $\mathbf{V}$ & $\mathbf{L}$ & $\mathbf{M}$ & Total \\
\hline Pre-test & 19.20 & 12.92 & 11.26 & 11.40 & 3.33 & 58.11 \\
\hline Cycle 1 & 23.88 & 13.17 & 13.92 & 12.83 & 3.58 & 67.37 \\
\hline Cycle 2 & 24.63 & 14.17 & 14.42 & 16.00 & 4.04 & 72.58 \\
\hline
\end{tabular}

\section{C: Content O: Organization V: Vocabulary L: Language Use M: Mechanics}

In addition, the students' improvement was not only found in writing skill but also in classroom situation. The improvements are presented in the table 2 .

Table 2. The students' improvement in classroom situation

\begin{tabular}{|l|l|l|l|}
\hline Indicators & Before the Action & Cycle One & Cycle Two \\
\hline $\begin{array}{l}\text { Students' poor writ- } \\
\text { ing skills that makes } \\
\text { students lazy to start } \\
\text { writing }\end{array}$ & $\begin{array}{l}\text { Some students chatted } \\
\text { with their friends in- } \\
\text { stead of focusing on } \\
\text { their writing task. }\end{array}$ & $\begin{array}{l}\text { The students did not } \\
\text { take long time to start } \\
\text { writing as they already } \\
\text { had ideas of what they } \\
\text { write. The students } \\
\text { write eagerly }\end{array}$ & $\begin{array}{l}\text { The students wrote } \\
\text { with their group en- } \\
\text { thuastically. }\end{array}$ \\
\hline $\begin{array}{l}\text { Low interest toward } \\
\text { writing, }\end{array}$ & $\begin{array}{l}\text { Some students seemed } \\
\text { not too interested in } \\
\text { the lesson especially } \\
\text { with the monotonous } \\
\text { Technique of teaching. }\end{array}$ & $\begin{array}{l}\text { The students partici- } \\
\text { pated actively during } \\
\text { the lesson and got in- } \\
\text { volved in the lesson. } \\
\text { The students also were } \\
\text { very interested to learn } \\
\text { by using picture }\end{array}$ & $\begin{array}{l}\text { Thed actively in writ- } \\
\text { ing class and enjoyed } \\
\text { in lesson }\end{array}$ \\
\hline $\begin{array}{l}\text { Inappropriate teach- } \\
\text { er's style in teaching }\end{array}$ & $\begin{array}{l}\text { The teacher used the } \\
\text { traditional method in } \\
\text { teaching }\end{array}$ & $\begin{array}{l}\text { The teacher utilize } \\
\text { Edublogs as media to } \\
\text { make teaching and } \\
\text { learning run well and } \\
\text { enjoyable }\end{array}$ & $\begin{array}{l}\text { The teacher was able } \\
\text { to create the enjoyable } \\
\text { atmosphere of learning } \\
\text { by using Edublogs as } \\
\text { the media. }\end{array}$ \\
\hline $\begin{array}{l}\text { The role of media } \\
\text { and the unsuitable } \\
\text { utilization of inter- } \\
\text { net facility. }\end{array}$ & $\begin{array}{l}\text { The use of media in the } \\
\text { classroom did not } \\
\text { function very well }\end{array}$ & $\begin{array}{l}\text { The teacher maximize } \\
\text { the existence of media, } \\
\text { Edublogs, in the class- } \\
\text { room }\end{array}$ & $\begin{array}{l}\text { The role of media was } \\
\text { vital to improve stu- } \\
\text { dents writing skill. }\end{array}$ \\
\hline
\end{tabular}

According to table above, it can be seen that there is a difference between cycle one and cycle two. It is assumed that the different result of research between cycle 1 and 2 happened for the reason that the researcher made some revised plans in order to make the cycle two better. The revised plans were made based on the unsolved problem that takes place in the cycle one. In cycle one, however, there were some unsolved problems related to students' writing skill. Those problems were: (1) vocabulary mistakes, especially the diction and context, (2) grammatical mistakes in the use of past tense and word order, (3) some students were not active in the group work and group discussion, (4) some students did not have confidence to answer questions during the classroom discussion. 
Considering those unresolved problems in cycle one, the study was furthermore continued to cycle two. In this cycle, the researcher did some stages that can solve problems in cycle one. To solve problem number 1 and 2, the teacher reviewed tense, diction and word order; to solve the problems in number 3 and 4 the researcher monitored the students' activities in group discussion. As a result, in cycle two, the researcher gave more practical exercises about the vocabulary, word order, punctuation, capitalization, and the use of past tense. The students practiced more frequently to create sentences and article on Edublogs. Thus, they practiced to create sentences using the correct tense, to choose the correct diction based on the context, and to use the correct word order.

\section{Conclusion}

The findings of this study demonstrated that the students scored higher in their writing assignments after having a treatment by using Edublogs as a teaching Media in teaching and learning. Edublogs in this study were used as tools to give the students an opportunity for collaboration. Furthermore, through using blogs, the students could also acquire knowledge and ideas from their peers' writings and apply them to their own writings. The class group blog was also a useful tool for the teacher, as it helped the teacher post documents such as syllabi, course expectations, and changes in the class schedules without having to mail each person individually.

There were some improvements that were related to the English teaching and learning process, the students, the English teacher, and the researcher. To the English teaching learning process, before actions were conducted, the students were unmotivated to participate in writing process. The writing learning process was monotonous. The teacher only used the course book without any media. During the implementation of the actions, Edublogs helped the teacher in learning process. The students were interested and enthusiastic to improve their skills. The English teaching and learning process in the writing process were more active and enjoyable than the previous condition, the classroom atmosphere was better, it was easy for the students to generate their ideas in a good generic structure, appropriate vocabulary, correct punctuation, and correct grammar. In addition, As the collaborator, the English teacher got more knowledge about the teaching writing using web blog. The teacher realized that the students needed many new things to direct their attention in all skills in English. The learning process looked easier because the use of media in the classroom. The last, to the researcher, it is trigger the researcher to improve teaching skill especially on how to manage the classroom and how to create the interesting activities. In addition, the researcher realized that the planning could not always be implemented in the class because unexpected events might occur in the classroom.

\section{References}

Fageeh, A. I. 2011. EFL Learners' Use of Blogging for Developing Writing Skills and Enhancing Attitudes towards English Learning: An Exploratory Study. Journal of Language and Literature, ISSN: 2078-0303, Vol. 2. No. 1. 2011.

Martindale, T. \& Wiley, D. (2005). Using weblogs in scholarship and teaching. TechTrends, 49(2), 55-61.

Ray, J. (2006). Welcome to the Blogosphere: The Educational Use of Blogs (aka Edublogs). Kappa Delta Pi Record, 42 (4), 175-177.

Raman, A., Don, Y., \& Daud, Y. (2015). Usage of EduBlogs Among Malaysian Secondary School Students. Mediterranean Journal of Social Sciences MCSER Publishing, Rome-Italy Vol 6 No 5 September $2015 \quad$ Doi:10.5901/ mjss.2015.v6n5p500

Asoodar, M., Atai, M. R., \& Vaezi, S. (2016). Blog-Integrated Writing with BlogBuddies. Journal of Educational Computing Research, 54(2), 225-252. doi:10.1177/0735633115615588

Boas, Isabela V. (2011). Process Writing and the Internet: Blogs and Ning Networks in the classroom. English Teaching Forum, v49 n2 p26-33

Foster, Drew. (2015) Private Journals versus Public Blogs: The Impact of Peer Readership on Low-stakes Reflective Writing. SAGE: Teaching Sociology 2015, Vol. 43(2) 104-114 DOI: 10.1177/0092055X14568204 
Eastman, D. (2005). Blogging. English Language Teacher Journal, 59(4), 358-361

Mynard, jo (2007). A blog as a Tool for Reflection for English Language Learners. Asian EFL Jurnal: Profesional teaching Articles Nov. 2007

Urbano, R.L. \& Villanueva P. A. (2012). The Use of Edublogs in University Classroom: An Educational Experience. International Conference Future Education:

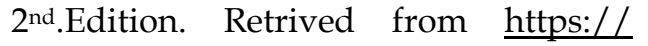
conference.pixel-online.net/ edu_future2012/common/download/ Paper_pdf/248-ENT22-FP-LagoFOE2012.pdf

Churchill, D. (2009), Educational applications of Web 2.0: Using blogs to support teaching and learning. British Journal of Educational Technology, 40: 179-183. doi:10.1111/j.1467-8535.2008.00865.x

Richards, Jack C. and Willy A. Renandya. 2002. Methodology in Language Teaching. Cambridge: Cambridge University Press.

Burns, Anne. 2010. Doing Action Research in English Language Teaching: a guide for practitioners. Cambridge: Routledge. 